\title{
Nutrient and Anti-Nutrient Composition of Shea (Vitellaria paradoxa C. F. Gaertn) Kernel and Pulp in the North East Nigeria
}

\author{
Matthew Olaleke Aremu1 , Hashim Ibrahim², Titilayo \\ Oluwayemisi Bamidele ${ }^{3}$, Rasaq Bolakale Salau ${ }^{4}$, Benjamin \\ Zobada Musa ${ }^{5}$, Francis Jide Faleye ${ }^{6}$
}

\author{
${ }^{1}$ Department of Chemical Sciences, Federal University Wukari, PMB 1020, Taraba State, Nigeria \\ ${ }^{2}$ Department of Chemistry, Federal University Lafia, PMB 146, Nasarawa State, Nigeria \\ ${ }^{3}$ Department of Biochemistry \& Molecular Biology, Nasarawa State University, PMB 1022, Keffi, Nigeria \\ ${ }^{4}$ Department of Chemistry, Federal University of Technology, Minna, Niger State, Nigeria \\ ${ }^{5}$ Department of Chemistry, Nasarawa State University, PMB 1022, Keffi, Nigeria \\ ${ }^{6}$ Department of Chemistry, Ekiti State University, PMB 5363, Ado-Ekiti, Nigeria
}

\begin{abstract}
This study determines the proximate, mineral, amino acid and anti-nutritional compositions of shea (Vitellaria paradoxa) kernel and pulp using standard analytical methods. The result showed that the contents of crude fat and protein in the kernel are higher than that of the pulp. The only minerals whose values ranged between 40.0 to $200 \mathrm{mg} / 100 \mathrm{~g}$ were $\mathrm{P}, \mathrm{Ca}$ and $\mathrm{Na}$ for the kernel and pulp samples but values of other minerals $(\mathrm{Mn}, \mathrm{Fe}, \mathrm{Zn}$, $\mathrm{K}, \mathrm{Cu}$ and $\mathrm{Mg}$ ) were below $10.00 \mathrm{mg} / 100 \mathrm{~g}$ on wet weight basis. Amino acid analysis of kernel and pulp showed concentrations of TAA (57.92 and $57.48 \mathrm{~g} / 100 \mathrm{~g}$ crude protein), TEAA (27.10 and $19.04 \mathrm{~g} / 100 \mathrm{~g}$ cp) and TNEAA (30.82 and $38.44 \mathrm{~g} / 100 \mathrm{~g} \mathrm{cp}$ ). Arginine was the most concentrated EAA in both the kernel and pulp samples. Except for the alkaloid, the kernel sample contained higher concentrations of anti-nutritional factors than the pulp. Generally, Vitellaria paradoxa kernel and pulp contained nutritive minerals and sufficient proportions of EAAs however, supplementation of all the EAAs will be required in order to meet up with FAO/WHO dietary requirements. Also the high contents of some of their anti-nutrients may pose a nutritional problem in their consumption.
\end{abstract}

Keyword: Vitellaria paradoxa, Kernel, Pulp, Proximate, Minerals, Amino Acids, Anti-Nutrients

\section{Introduction}

Shea butter is an extract from the seed of shea nuts tree (Vitellaria paradoxa formerly known as Butryspermum paradoxum, $B$. parkii and $B$. paradoxa) belonging to Sapotaceae family - has been used for a wide range of cosmetics products. It has also been used for ethno-pharmacological purposes. For instance, local healers have used shea butter for the treatment of nostril inflammation, nasal congestion, minor bone dislocation, cough, leprosy and rheumatism [1, 2]. Shea butter has been used in addition, to massage newly born babies, protect against Simulium infection as insect repellent and prevent stretch marks among African pregnant women [2]. Furthermore, shea butter has served in African kitchen as edible oil due to its price affordability and highly nutritional value [3, 4]. For example, shea butter is used in northern Nigeria as the base of soup and condiments.

Diets in developing economies like Nigeria are predominantly based on poorly digestible proteins from less refined cereals and grain legumes, which contain high levels of less-digestible protein fractions, high levels of insoluble fibre and high concentrations of anti-nutritional factors [5]. Antinutritional factors may occur endogenously or may be formed during heat/alkaline processing of proteins. The examples of major naturally occurring anti-nutritional factors include trypsin inhibitors and haemagglutinins in legumes; tannins in legumes and cereals; phytates in cereals and oilseeds; glucosinolates in canola and mustard protein products; gossypol in cottonseed protein products;

This article is published under the terms of the Creative Commons Attribution License 4.0

Author(s) retain the copyright of this article. Publication rights with Alkhaer Publications.

Published at: http://www.ijsciences.com/pub/issue/2018-09/

DOI: 10.18483/ijSci.1811; Online ISSN: 2305-3925; Print ISSN: 2410-4477 
and uricogenic nucleic acid bases in yeast protein products $[5,6,7]$.

In Nigeria, the shea-butter tree occurs mainly across the wide expanse of Guinea and Sudan savanna zones otherwise known as savanna belt [8, 9]. Hence, this wide distribution and high concentration of the trees presumably accounts for Nigeria's position as the leading producer of shea nuts in Africa [10]. Unfortunately, very little information exists on amino acids composition of shea-butter fruit (both kernel and pulp) found in the savanna/shea belt of Nigeria. Therefore, in order to find means of enriching diets of rural communities within the shea belt and to raise the nutritional potential of shea-butter fruit, we deemed it is important to assess the chemical composition of the shea-butter fruit (kernel and pulp) grown in northeast, Nigeria so as to provide the much needed information on the nutritive values (proximate, minerals and amino acids) and anti-nutritional factors (saponin, tannin, alkaloid, oxalate, cyanide and phytate).

\section{Materials and Methods}

\section{Collection and preparation of samples}

Fresh shea-butter fruits were collected from a small farm at Wukari, Taraba State (Northern guinean savanna), Nigeria. The fruits were de-pulped and the fruit pulp, comprising the epicarp and mesocarp, were oven-dried (between $40{ }^{\circ} \mathrm{C}$ and $50{ }^{\circ} \mathrm{C}$ ) to a constant weight for five days. The de-pulped seeds of the shea-butter fruit were cracked to remove the kernel which was also oven-dried at the same temperature range for 4 days. Dried samples were finely milled for laboratory analysis.

\section{Proximate analysis}

The moisture, ash, crude fat, crude protein $(\mathrm{N} x$ 6.25 ), crude fibre and carbohydrate (by difference) were determined in accordance with the standard methods of AOAC [11]. All proximate analyses of the sample flours were carried out in triplicate and reported in percentage. All chemicals were of Analar grade.

\section{Mineral analysis}

The standards of $\mathrm{K}, \mathrm{Na}, \mathrm{Ca}, \mathrm{Mg}, \mathrm{Mn}, \mathrm{Fe}, \mathrm{Cu}$ and $\mathrm{Zn}$ solutions of $0.2,0.4,0.6,0.8$ and $1.0 \mathrm{mgL}^{-1}$ were prepared from each of the metal solutions of 1000 $\mathrm{mgL}^{-1}$ stock solutions. The filtrates of the digested samples were analysed by atomic absorption spectrophotometer (AAS). The detection limit of the metals in the sample was $0.000 \mathrm{mgL}^{-1}$ by means of the UNICAM 929, London, atomic absorption spectrophotometer powered by the solar software. The optimal analytical range was 0.1 to 0.5 absorbance units with coefficient of variation from $0.9 \%$ to $2.21 \%$. Phosphorus was determined colorimetrically [12] using a Spectronic 20 (Gallenkamp, London, UK) instrument, with $\mathrm{KH}_{2} \mathrm{PO}_{4}$.

\section{Amino acid analysis}

The amino acid analysis was by Ion Exchange Chromatography (IEC) [13] using the Technico Sequential Multisample (TSM) Amino Acid Analyzer (Technicon Instruments Corporation, New York). The period of analysis was $76 \mathrm{~min}$ for each sample. The gas flow rate was $0.50 \mathrm{mLmin}^{-1}$ at $60^{\circ} \mathrm{C}$ with reproducibility consistent within $\pm 3 \%$. The net height of each peak produced by the chart recorder of the TSM (each representing an amino acid) was measured and calculated. Amino acid values reported were the averages of two determinations. Nor-leucine was the internal standard. Tryptophan was determined after alkali $(\mathrm{NaOH})$ hydrolysis by the colorimetric method [14].

Determination of isoelectric point (pI), quality of dietary protein and predicted protein efficiency ratio (P-PER)

The predicted isoelectric point was evaluated according to Olaofe \& Akintayo [15]:

$$
p l m=\sum_{i=1}^{n=1} p l i X i \quad----(1)
$$

\section{Where:}

$\mathbf{p I m}=$ the isoelectric point of the mixture of amino acids;

$\mathbf{p I i}=$ the isoelectric point of the ith amino acids in the mixture;

$\mathbf{X i}=$ the mass or mole fraction of the amino acids in the mixture.

The quality of dietary protein was measured by finding the ratio of available amino acids in the sample protein compared with the needs expressed as a ratio. Amino acid score (AAS) was then estimated by applying the FAO/WHO [13] formula:

$$
A A S=\frac{m g \text { of amino acid in } 1 g \text { of test protein }}{m g \text { of amino acid in reference protein }} \times \frac{100}{1}----(2)
$$

The predicted protein efficiency ratio (P-PER) of the seed sample was calculated from their amino acid composition based on the equation developed by Alsmeyer et al. [16] as stated thus;

P-PER $=-0.468+0.454($ Leu $)-0.105(\mathrm{Tyr}) \ldots \ldots \ldots$ 


\section{Anti-nutritional Factors Determination}

The contents of saponin, tannin, alkaloid, phytate, oxalate and cyanide were determined on each of the sample flours by methods described by some workers [17, 18].

\section{Statistical analysis of the samples}

The fatty acid values were obtained by multiplying crude fat value of each sample with a factor of 0.8 (i.e. crude fat $\times 0.8=$ corresponding to fatty acids value [19]. The energy values were calculated by adding up the carbohydrate $\mathrm{x} 17 \mathrm{~kJ}$, crude protein $\mathrm{x}$ $17 \mathrm{~kJ}$ and crude fat $\mathrm{x} 37 \mathrm{~kJ}$ for each of the samples [20]. Errors of three determinations were computed as standard deviation (SD) for the proximate composition. The grand mean, SD and coefficient variation (RSD) were also determined.

\section{Results and Discussion}

Proximate composition is important in determining the quality of food materials and often the basis for establishing their overall nutritional value. Table 1 depicts the proximate compositions of kernel and pulp of Vitellaria paradoxa. The kernel and pulp sample values were: $4.41 \%$ and $9.72 \%, 3.17 \%$ and $4.78 \%, 45.62 \%$ and $10.95 \%, 9.30 \%$ and $5.23 \%$, $4.73 \%$ and $6.57 \%$ and $32.77 \%$ and $62.77 \%$ for moisture, ash, crude fat, crude protein, crude fibre and carbohydrate, respectively. The calculated fatty acids and metabolizable energy were 36.50 and $8.76 \% ; 2403.13$ and $1560.88 \mathrm{~kJ} / 100 \mathrm{~g}$, respectively.

Table 1: Proximate composition (\%) $)^{\text {a }}$ of kernel and pulp of Vitellaria paradoxa

\begin{tabular}{lccccc}
\hline \multicolumn{1}{c}{ Parameter } & Kernel & Pulp & Mean & SD & RSD \\
\hline Moisture & $4.41 \pm 0.19$ & $9.72 \pm 0.22$ & 7.07 & 2.66 & 37.62 \\
Ash & $3.17 \pm 0.08$ & $4.78 \pm 0.23$ & 3.98 & 0.81 & 20.35 \\
Crude fat & $45.62 \pm 0.29$ & $10.95 \pm 0.56$ & 28.29 & 17.34 & 61.29 \\
Crude protein & $9.30 \pm 0.11$ & $5.23 \pm 0.27$ & 7.27 & 2.04 & 28.06 \\
Crude fibre & $4.73 \pm 0.29$ & $6.57 \pm 0.11$ & 5.65 & 0.92 & 16.28 \\
Carbohydrate $^{\mathbf{b}}$ & $32.77 \pm 0.15$ & $62.77 \pm 0.91$ & 47.77 & 15.00 & 31.4 \\
Fatty acid $^{\mathbf{c}}$ & $36.50 \pm 0.24$ & $8.76 \pm 0.45$ & 22.63 & 13.87 & 61.29 \\
Energy $^{\text {d }}$ & $2403.13 \pm 15.15$ & $1560.88 \pm 9.57$ & 1982.01 & 421.13 & 21.25 \\
\hline
\end{tabular}

${ }^{a}$ Mean values \pm standard deviations of triplicate determinations; ${ }^{b}$ Carbohydrate percent calculated as the $(100-$ total of other components); ${ }^{\mathrm{c}}$ Calculated fatty acid ( $0.8 \times$ crude fat)

${ }^{\mathbf{d}}$ Calculated metabolizable energy (kJ/100 g) (protein x 17 + fat x 37 + carbohydrate x 17)

$\mathrm{SD}=$ Standard deviation; RSD = Relative standard deviation.

The moisture contents obtained for the kernel and pulp of Vitellaria paradoxa varied significantly with those obtained for soursop (10.97\%), Pterygota macrocarpa (10.38\%), Hexalobus crispiflorus (7.11\%), Bracystegia eurycoma harm (10.60\%), Clitandra togolana $(10.81 \%)$ and Adansonia digitata pulp $(10.90 \%)$ as reported by many researchers [21 - 26]. The results however, are higher when compared to the seed of Maesobotry barteri fruit $(3.85 \%)$ [27], leaves of Moringa oleifera $(3.21 \%)$ [28], Haematostaphis barteri seed (2.75\%) and pulp (3.56\%) [29], Adansonia digitata seed $(3.50 \%)$ [26] and kersting's groundnut (1.7\%) [30]. Moisture content in foods has an important relationship between conservation and the physical, chemical and microbiological changes during the storage [31]. Moderate moisture content of $\leq 12 \%$ is preferred for shelf stability of food on long storage [32].

Fiber intake is largely important due to its physiological effects that have benefit health implications [33]. Strong correlations exist between the moisture contents and crude fiber which could be of interest to human health as the fibrous are easily digested and disintegrate. Crude fibers in the diet are necessary for digestion and for effective elimination of wastes. It can lower the serum cholesterol, the risk of coronary heart disease, hypertension, constipation, varicose veins, diabetes, phlebitis, obesity, cancer of breast, rectum and colon cancer and even threat of gastrointestinal disorders [34 35]. The fibre content values obtained in the kernel $(4.73 \%)$ and pulp $(6.57 \%)$ samples of Vitellaria paradoxa exceed that of $P$. guineense schum and thonn $(4.20 \%)$ [24], T. triangulare $(2.40 \%), T$. occidentalis (1.7\%) and C. argentea (1.8\%) [36] and cowpea $(3.60 \%)$ [37].

Ash contains mineral materials of the food/plant because ashing destroys all the organic material present in the sample. Ash is also an indicative of high digestibility of the plant [38]. Findings of present study indicate that there are more minerals in the pulp (4.78\%) than the kernel $(3.17 \%)$, the values of ash content are comparable favourably to those 
reported for Lophira lanceolata (1.45\%) [38], pulp of Haematostaphis barteri (2.97\%) [29], seed of Adansonia digitata (2.80\%) [26] and some leafy vegetable such as Solanium nodiflorum (ogumo) $(2.67 \%)$ [39]. Protein is viewed as the most expensive component of any diet, and is an essential ingredient forming part of a healthy balanced diet. It plays an important role in nutrition through catalyzing, regulating, protecting and providing energy [40]. The observed crude protein content for both the kernel $(9.30 \%)$ and pulp $(5.23 \%)$ of Vitellaria paradoxa are lower than the reported values for Momordica balsamina (11.29\%), Moringa oleifera (20.72\%), Lesianthera africiana leaves $(13.10-14.90 \%)$ and Leptadenia hastate (19.10\%) [41], cowpea (24.13\%) [42], pigeon pea $(21.53 \%)$ [43], bambara groundnut $(24.44 \%)$ [44], and kersting's groundnut (12.90\%) [30]. Ene-Obong [45] reported that diet is nutritionally satisfactory if it contains high calorie value and a sufficient amount of protein. Some scholars also stated that any plant food that provide about $12 \%$ of their caloric value from protein are considered good sources of protein $[46,47]$. Thus, neither the seed nor the pulp is a good source of protein.

Fat provides very good sources of energy and aids in transport of fat soluble vitamins, insulates and protects internal tissues and contributes to important cell processes [48]. The crude fat content of kernel and pulp of Vitellaria paradoxa were 45.62 and $10.95 \%$, respectively. This qualifies Vitellaria paradoxa kernel $(45.62 \%)$ as an oil-rich food, since it is comparable with soybean $(22.8-23.5 \%)$ [49, 50]. The crude fat percentage of Vitellaria paradoxa kernel appears good when rated against the $20-50$ reported by Maranz and Wiesman [51]. According to these authors, crude lipid between 20 and $30 \%$ are low, those above $30.5 \%$ are intermediate and values above $40 \%$ are good. Such classification would place shea - kernel crude lipid/fat from the northern guinean savanna of Nigeria (Wukari, Taraba State) under good lipid content group.

The carbohydrate contents of $32.77 \%$ in the kernel and $62.77 \%$ in the pulp showed that shea-butter kernel and pulp can be categorized as carbohydrate rich food. The carbohydrate content of the pulp is higher than $47.00 \%$ and $44.60 \%$ reported for $A$. muricata [52] and Adansonia digitata L. [53]. Relatively high energy value of 2403.13 and $1560.88 \mathrm{~kJ} / 100 \mathrm{~g}$ for Vitellaria paradoxa kernel and pulp, respectively indicates that the fruit is a concentrated source of energy and within the recommended energy dietary allowances for children [54]. It equally implies that promoting consumption of shea-butter fruit is of great benefit to the human diet. The high fatty acid value obtained for the kernel (36.50) is an indication that the oil from the kernel of Vitellaria paradoxa may not be suitable for use in cooking (edibility), but however, be useful for industrial purposes [55]. The RSD is highly varied in some parameters: Moisture (37.62), crude fat (61.29) and calculated fatty acids (61.29) while the parameter with least RSD was crude fibre (16.28) (Table 1).

Table 2: Mineral composition (mg/100 g) of kernel and pulp of Vitellaria paradoxa on wet weight basis

\begin{tabular}{cccccc}
\hline Mineral & Kernel & Pulp & Mean & SD & RSD \\
\hline $\mathrm{Na}$ & 118.31 & 174.93 & 146.62 & 28.31 & 19.31 \\
$\mathrm{Ca}$ & 59.41 & 62.46 & 60.94 & 1.53 & 0.03 \\
$\mathrm{~K}$ & 2.75 & 0.17 & 1.46 & 1.29 & 88.36 \\
$\mathrm{Mn}$ & 0.34 & 0.38 & 0.36 & 0.02 & 5.56 \\
$\mathrm{Mg}$ & 6.29 & 4.83 & 5.56 & 0.73 & 13.13 \\
$\mathrm{Cu}$ & 3.92 & 3.26 & 3.59 & 0.33 & 9.19 \\
$\mathrm{Zn}$ & 2.68 & 2.02 & 2.35 & 0.33 & 14.04 \\
$\mathrm{Fe}$ & 0.91 & 1.11 & 1.01 & 0.1 & 9.90 \\
$\mathrm{P}$ & 58.22 & 41.67 & 49.95 & 8.28 & 16.57 \\
$\mathrm{Ca} / \mathrm{P}$ & 1.02 & 1.50 & 1.26 & 0.24 & 19.05 \\
$\mathrm{Na} / \mathrm{K}$ & 43.02 & 1029.0 & 536.01 & 492.99 & 91.97 \\
$\mathrm{Na} / \mathrm{Mg}$ & 18.81 & 36.22 & 27.52 & 8.71 & 31.63 \\
\hline
\end{tabular}

$\mathrm{Ca} / \mathrm{P}=$ Calcium to phosphorous ratio; $\mathrm{Na} / \mathrm{K}$ = Sodium to potassium ratio; $\mathrm{Na} / \mathrm{Mg}$ = Sodium to magnesium ratio; $\mathrm{SD}=$ Standard deviation; RSD = Relative standard deviation .

The most abundant mineral in seed and pulp samples was sodium (118.31 and 174. $93 \mathrm{mg} / 100 \mathrm{~g}$, respectively) while the least was Fe (0.91 and 1.11 $\mathrm{mg} / 100 \mathrm{~g})$. The values $(\mathrm{mg} / 100 \mathrm{~g})$ of other essential minerals in the kernel and pulp were $\mathrm{Ca}$ (59.41 and 62.46), K (2.75 and 0.17), Mg (6.29 and 4.83) and P 
(58.22 and 41.67). Calcium in conjunction with phosphorous, magnesium, vitamin $\mathrm{A}, \mathrm{C}$ and $\mathrm{D}$, calorie and protein are all in involved in bone formation [56]. Calcium is also important for blood clotting, muscle contraction and in certain enzymes in metabolic processes [57]. Magnesium is an activator of many enzyme systems and maintains the electrical potential in nerves [57]. Phosphorous assists calcium in many body reactions, although it also has independent functions. It has been reported that modern diets that are rich in phosphorus and animal proteins may promote the loss of calcium in the urine [58]. This has lead to the concept of calcium to phosphorous ratio. If the ratio is low (low $\mathrm{Ca}$ high $\mathrm{P}$ intake) more than the normal amount of $\mathrm{Ca}$ may be lost in the urine. Food is considered 'good' if $\mathrm{Ca} / \mathrm{P}$ ratio is above ' 1 ' and 'poor' if the ratio is less than ' 0.5 ' while a $\mathrm{Ca} / \mathrm{P}$ ratio above ' 2 ' helps to increase the absorption of $\mathrm{Ca}$ in the small intestine. The result of $\mathrm{Ca} / \mathrm{P}$ ratio in the two samples was good: kernel (1.02), pulp (1.50). The ratio of $\mathrm{Na} / \mathrm{K}$ in the body is of great concern for the prevention of high blood pressure. $\mathrm{A} \mathrm{Na} / \mathrm{K}$ ratio less than ' 1 ' is recommended; however the kernel and pulp of Vitellaria paradoxa may not be able to prevent blood pressure because the $\mathrm{Na} / \mathrm{K}$ ratio is far greater than ' 1 '. The ratio of $\mathrm{Na} / \mathrm{Mg}$ is higher than the normal range (4.00). The adrenal glands play an essential role in regulating sodium retention and excretion. Studies have also shown that $\mathrm{Mg}$ will affect adrenal cortical activity and results in increased $\mathrm{Mg}$ retention [59]. The $\mathrm{Na}-\mathrm{Mg}$ profile is indicative of reduced adrenal cortical function. Zinc and copper are intricately related to the hormones, progesterone and estrogens, respectively; and their tissue levels may be indirectly reflective of the status of these hormones within the body [59]. The values recorded for $\mathrm{Zn}$ and $\mathrm{Cu}$ in the present study were 2.68 and 2.02, 3.92 and $3.26 \mathrm{mg} / 100 \mathrm{~g}$ for the kernel and pulp, respectively. The RSD varied with a range of 0.03-91.97 (Table 2).

The results of amino acid composition of kernel and pulp samples of Vitellaria paradoxa are shown in Table 3. Glu and Arg were the most concentrated in kernel sample with the respective value $(\mathrm{g} / 100 \mathrm{~g}$ crude protein) of 10.14 and 7.14, while Pro and Glu were the most concentrated in pulp sample with $15.23 \mathrm{~g} / 100 \mathrm{~g}$ and $6.97 \mathrm{~g} / 100 \mathrm{~g} \mathrm{cp}$, respectively. Arg was the most concentrated essential amino acid in both samples with $7.14 \mathrm{~g} / 100 \mathrm{~g}$ and $3.01 \mathrm{~g} / 100 \mathrm{~g} \mathrm{cp}$ for the kernel and pulp sample, respectively. The least was Try $(0.75$ and $0.50 \mathrm{~g} / 100 \mathrm{~g} \mathrm{cp})$ in kernel and pulp. Arginine is an essential amino acid which has direct antioxidant activity [60] and is also necessary for children growth [61]. The Arg is only considerably high in the kernel sample. The Lys content in the kernel sample $(3.05 \mathrm{~g} / 100 \mathrm{~g} \mathrm{cp})$ is found to be higher than that of L. cylindrica kernel (2.9 g/100 g cp) [62], while the Met content (1.55 $\mathrm{g} / 100 \mathrm{~g} \mathrm{cp}$ ) for the kernel sample is higher than that reported by Olubunmi et al. [63] for A. cruenthus (0.93 g/100 g cp), C. olitorius (0.75 g/100 g cp), C. chayamansa $(0.80 \mathrm{~g} / 100 \mathrm{~g} \mathrm{cp})$ and $B$. alba $(0.67$ $\mathrm{g} / 100 \mathrm{~g} \mathrm{cp})$. The concentrations of Val $(3.04 \mathrm{~g} / 100 \mathrm{~g}$ cp kernel and $2.89 \mathrm{~g} / 100 \mathrm{~g}$ cp pulp) and Ile (1.83 $\mathrm{g} / 100 \mathrm{~g}$ cp kernel and $1.34 \mathrm{~g} / 100 \mathrm{~g}$ cp pulp) were found not to meet the FAO/WHO/UNU [64] requirement for these two EAA $(3.50 \mathrm{~g} / 100 \mathrm{~g} \mathrm{cp}$ and $2.80 \mathrm{~g} / 100 \mathrm{~g} \mathrm{cp}$, respectively) for pre-school children aged 2-5 years.

Ile is an essential amino acid for both young and old. Met is needed for the synthesis of choline which in turn forms lecithin and other phospholipids in the body. When the diet is low in protein, for instance in alcoholism and kwashiorkor, insufficient choline may be formed; this may cause accumulation of fat in the liver [65]. Other EAAs with appreciable contents obtained in the analyzed samples include Phe $(3.02 \mathrm{~g} / 100 \mathrm{~g} \mathrm{cp})$, Leu (4.12 g/100 g cp) and Try (0.75 g/100 g cp), all in the kernel sample. Phe is the precursor of some hormones and the pigment melanin in hair, eyes and tanned skin [63]. It has been explained by Gold [66] that Phe is needed in treating brain disorder, normal functioning of the central nervous system, control of symptoms of depression and chronic pain, while Try is important in the manufacture of neurotransmitter serotonin, which regulates mood and sleep pattern, treatment of jet lag, depression and binge eating. Try is also required for the treatment of vascular migraines, panic attacks, rheumatoid arthritis, and normal functioning of the central nervous system [67]. Leu, Ile and Val (branched-chain amino acids) work together to repair muscles, regulate blood sugar and provide body with energy.

The predicted protein efficiency ratio ( $\mathrm{P}-\mathrm{PER})$ is one of the quality parameters used for protein evaluation [13]. $\mathrm{P}-\mathrm{PER}$ value in this report for kernel sample (1.17) is higher than the reported $\mathrm{P}$ PER values of Adansonia digitata pulp (1.10) [26] and Lathynis sativus L. (1.03) [50], but lower than those reported by Audu and Aremu [68] (2.5), Oyetayo and Ojo [69] (1.89) and Aremu et al. [70] (2.77) for red kidney bean, L. cylindrica and tiger nut, respectively. The calculated isoelectric point (pI) is of significance in protein purification. The Vitellaria paradoxa kernel had the highest calculated pI of 6.03 which is the point at which the protein should accumulate during purification. The Lys/Arg ratio has been reported to play a role in the artherogenocity of a protein. Kritchevsky [71] 
reported that a Lys/Arg ratio as high as 2.0, increases the artherogenic potential of a diet. However, the Lys/Arg ratios of both the kernel (0.43) and pulp (0.73) of Vitellaria paradoxa were very low. Thus the shea-butter kernel and pulp may possess a low artherogenic potential.

Some studies suggested that the Leu/Ile balance is more important than dietary excess of Leu alone [72, 73]. As excessively high intake of Leu has been linked to the development of pellagra, a deficiency of the vitamin niacin that cause diarrhea, mental disorder and dermatitis. Too much Leu in the diet can also disrupt kidney and liver function and increase the amount of ammonia in the body. The Leu/Ile ratios in the samples (2.10 and 2.25) were relatively not high. Generally, the above mentioned amino acids were low in both samples but comparatively higher in the kernel. The RSD varied with a range of 1.00 in calculated pI to 74.46 in Pro (Table 3).

Table 3: Amino acid composition (g/100 $\mathrm{g} \mathrm{cp}$ ) of kernel and pulp of Vitellaria paradoxa

\begin{tabular}{|c|c|c|c|c|c|}
\hline Amino acid & Kernel & Pulp & Mean & SD & RSD \\
\hline Lysine (Lys) ${ }^{\mathbf{e}}$ & 3.05 & 2.20 & 2.63 & 0.43 & 16.19 \\
\hline Histidine (His) ${ }^{\mathbf{e}}$ & 0.77 & 0.89 & 0.83 & 0.06 & 7.23 \\
\hline Arginine $(\mathrm{Arg})^{\mathbf{e}}$ & 7.14 & 3.01 & 5.08 & 2.07 & 40.69 \\
\hline Aspartic acid (Asp) & 4.57 & 3.60 & 4.09 & 0.49 & 11.87 \\
\hline Threonine (Thr) ${ }^{\text {e }}$ & 1.83 & 2.55 & 2.19 & 0.36 & 16.44 \\
\hline Serine (Ser) & 3.32 & 2.22 & 2.77 & 0.55 & 19.86 \\
\hline Glutamic acid (Glu) & 10.14 & 6.97 & 8.56 & 1.59 & 18.53 \\
\hline Proline (Pro) & 2.23 & 15.23 & 8.73 & 6.50 & 74.46 \\
\hline Glycine (Gly) & 3.82 & 3.37 & 3.60 & 0.23 & 6.26 \\
\hline Alanine (Ala) & 3.41 & 3.19 & 3.30 & 0.11 & 3.33 \\
\hline Cystine (Cys) & 1.09 & 1.45 & 1.27 & 0.18 & 14.17 \\
\hline Valine $(\mathrm{Val})^{\mathrm{e}}$ & 3.04 & 2.89 & 2.97 & 0.08 & 2.53 \\
\hline Methionine (Met) ${ }^{\mathbf{e}}$ & 1.55 & 0.67 & 1.11 & 0.44 & 39.64 \\
\hline Isoleucine (Ile) ${ }^{\mathbf{e}}$ & 1.83 & 1.34 & 1.59 & 0.25 & 15.46 \\
\hline Leucine (Leu) ${ }^{\mathbf{e}}$ & 4.12 & 2.86 & 3.49 & 0.63 & 18.05 \\
\hline Tyrosine (Tyr) & 2.24 & 2.41 & 2.33 & 0.09 & 3.66 \\
\hline Tryptophan (Try) ${ }^{\mathbf{e}}$ & 0.75 & 0.50 & 0.63 & 0.13 & 20.00 \\
\hline Phenylalanine (Phe) ${ }^{\mathbf{e}}$ & 3.02 & 2.13 & 2.58 & 0.45 & 17.28 \\
\hline Isoelectric point (pI) & 6.03 & 5.92 & 5.98 & 0.01 & 1.00 \\
\hline P-PER & 1.17 & 0.56 & 0.87 & 0.31 & 35.63 \\
\hline Leu/Ile & 2.25 & 2.10 & 2.18 & 0.08 & 3.67 \\
\hline Lys/Arg & 0.43 & 0.73 & 0.58 & 0.15 & 25.86 \\
\hline
\end{tabular}

${ }^{\mathbf{e}}$ Essential amino acid; P-PER = Predicted protein efficiency ratio; SD = Standard deviation; RSD = Relative standard deviation.

The quality of a protein depends primarily on its capacity to satisfy the needs for nitrogen and essential amino acids [74]. Table 4 depicts the essential, non - essential, acidic, neutral and sulphur containing amino acids. The total amino acid (TAA) was 57.92 and $57.48 \mathrm{~g} / 100 \mathrm{~g}$ cp for kernel and pulp samples, respectively. These values are higher than the $42.48 \mathrm{~g} / 100 \mathrm{~g} \mathrm{cp}$ (B. eurycoma) and $48.13 \mathrm{~g} / 100$ g cp (B. sapida) reported by many researchers [24, 75]. But the values are lower to those reported for the seeds of Mucana puriens var pruriens (92.43 g/100 g) [76], Lophira lanceolata seeds (355.01 $\mathrm{g} / 100 \mathrm{~g})$ [77] and fermented cocoa nibs (70.8 g/100 g). The EArAA ranged from $2.63-3.77 \mathrm{~g} / 100 \mathrm{~g} \mathrm{cp}$ which is averagely lower than the ideal range suggested for infant protein $(6.8-11.8 \mathrm{~g} / 100 \mathrm{~g} \mathrm{cp})$ [64]. The aromatic amino acids are precursors of epinephrine and thyroxin [61]. Though the concentrations of total sulphur amino acids (TSAA) which ranged from $1.21-2.59 \mathrm{~g} / 100 \mathrm{~g}$ cp are lower than the $5.8 \mathrm{~g} / 100 \mathrm{~g} \mathrm{cp}$ recommended for infants FAO/WHO [78]; the \% Cys in TSAA found in the pulp sample is greater than the reported value for Parkia biglobossa seeds (44.4\%) and $O$. gratissimum (46.67\%) [79]. It has also been reported that most animal proteins are low in Cys and hence in Cys/TSAA ratio, for instance, $21.0 \%, 38.8 \%$ and $35.5 \%$ were reported for Limicolaria sp, A. archantina and A. marginata, respectively [80]. Cys is known to pair with Met in improving protein quality and it also has positive effects on mineral absorption, particularly Zn [24, 81].

The \% TNEAA was $53.21 \%$ while \% TEAA (with His) and \%TEAA (without His) were $46.79 \%$ and $45.46 \%$, respectively for the kernel sample. This is 
Nutrient and Anti-Nutrient Composition of Shea (Vitellaria paradoxa C. F. Gaertn) Kernel and Pulp in the North East Nigeria

an indication that the kernel protein is of high quality. It can also be observed that the \%TEAA for the kernel sample in this report is well above the $39 \%$ considered to be adequate for ideal protein food for infants, $26 \%$ for children and $11 \%$ for adults [64]. The $\%$ of TNAA is $55.68 \%$ (kernel) and $71.00 \%$ (pulp) meaning that the bulk of the amino acids in both samples are neutral. Percentage total acidic amino acids (TAAA) were 25.40 (kernel) and 18.39 (pulp) which are lower than \% TNAA, whilst that of total basic amino acids (TBAA) were 18.92 (kernel) and 10.61 (pulp) which made them the third largest group among the parameters.

Table 4: Concentrations of essential, non-essential, acidic, basic, neutral, sulphur, aromatic, etc. (g/100 g cp) amino acid of kernel and pulp of Vitellaria paradoxa

\begin{tabular}{lcc}
\hline \multicolumn{1}{c}{ Amino acid description } & Kernel & Pulp \\
\hline Total amino acid (TAA) & 57.92 & 57.48 \\
\%otal non-essential amino acid (TNEAA) & 30.82 & 38.44 \\
Total essential amino acid (TEAA) & 53.21 & 66.88 \\
With histidine & & 19.04 \\
Without histidine & 27.10 & 18.15 \\
WEAA & 26.33 & 33.12 \\
With histidine & & 31.58 \\
Without histidine & 46.79 & 9.64 \\
Essential alphatic amino acid (EAAA) & 45.46 & 2.63 \\
Essential aromatic amino acid (EArAA) & 10.82 & 40.81 \\
Total neutral amino acid (TNAA) & 3.77 & 71.00 \\
TNAA & 32.25 & 10.57 \\
Total acidic amino acid (TAAA) & 55.68 & 18.39 \\
TAAA & 14.71 & 6.10 \\
Total basic amino acid (TBAA) & 25.40 & 10.61 \\
TBAA & 10.96 & 2.12 \\
Total sulphur amino acid (TSAA) & 18.92 & 68.40 \\
\hline
\end{tabular}

Table 5: Amino acid scores of kernel and pulp of Vitellaria paradoxa based on FAO/WHO standards

\begin{tabular}{cccccc}
\hline \multirow{2}{*}{ EAA } & $\begin{array}{c}\text { PAAESP g/100g } \\
\text { protein }\end{array}$ & $\begin{array}{c}\text { Kernel } \\
\text { EAAC }\end{array}$ & AAS & EAAC & Pulp \\
\hline Ile & 4.0 & 1.83 & 0.46 & 1.34 & 0.34 \\
Leu & 7.0 & 4.12 & 0.59 & 2.86 & 0.41 \\
Lys & 5.5 & 3.05 & 0.55 & 2.20 & 0.40 \\
Met + Cys (TSAA) & 3.5 & 2.64 & 0.75 & 2.12 & 0.61 \\
Phe + Tyr & 6.0 & 5.26 & 0.88 & 4.54 & 0.76 \\
Thr & 4.0 & 1.83 & 0.46 & 2.55 & 0.64 \\
Try & 1.0 & 0.75 & 0.75 & 0.50 & 0.50 \\
Val & 5.0 & 3.04 & 0.61 & 2.89 & 0.58 \\
Total & $\mathbf{3 6 . 0}$ & $\mathbf{2 2 . 5 2}$ & $\mathbf{5 . 0 5}$ & $\mathbf{1 9 . 0 0}$ & $\mathbf{4 . 2 4}$ \\
\hline
\end{tabular}

EAA = Essential Amino Acid; PAAESP = Provisional Amino Acid (Egg) Scoring Pattern; EAAC = Essential

Amino Acid Composition; AAS = Amino Acid Score

Results of essential amino acid scores based on the provisional amino acid scoring pattern [13] standards are shown in Table 5. The essential amino acid contents in this report are lower than the FAO/WHO [13] recommended pattern. Thus by implication, dietary formula based on the kernel and pulp samples of Vitellaria paradoxa will require essential amino acids supplementation. Generally, the EAAs that most often act in a limiting capacity are Met (and Cys), Lys and Try [64]. In this study,
Ile (0.46 and 0.34) and Lys (0.55 and 0.40) are the first and second limiting amino acids (LAA) for both the kernel and pulp samples, respectively.

Dietary anti-nutritional factors such as tannin, phytate, cyanide, alkaloid, oxalate and saponin have been reported to adversely affect the digestibility of protein, bioavailability of amino acids and protein quality of foods [82]. Table 6 presents the antinutritional properties of Vitellaria paradoxa. The tannin contents (5.46 and $14.03 \mathrm{mg} / 100 \mathrm{~g}$ ) are 
considered high when compared with the value $(0.017-0.103 \%)$ for cucurbita fruits, $2.56 \%$ reported for cuban boa (Epicrates anquifer) [83], and 3.8 and $4.56 \%$ for two medicinal plants Senna alata and Cajanus cajan [84]. But the contents are lower than the $21.19 \%$ observed for Moringa oleifera leaves [28]. Another study shows that tannin usually forms insoluble complexes with proteins, thereby interfering with their bioavailability [85]. This will result in reducing the protein and amino acid digestibility. The poor palatability of food is generally attributed to high content of tannins (Mehansho et al., 1987). Tannins are also capable of lowering the available protein by antagonistic competition and therefore eliciting protein deficiency syndrome Kwashiorkor.

Table 6: Anti-nutritional properties of kernel and pulp of Vitellaria paradoxa

\begin{tabular}{lccccc}
\hline \multicolumn{1}{c}{ Parameter } & Kernel & Pulp & Mean & SD & RSD \\
\hline Oxalate $(\mathrm{mg} / 100 \mathrm{~g})$ & 649.00 & 221.50 & 435.25 & 213.75 & 49.11 \\
Saponin $(\%)$ & 8.15 & 0.24 & 4.2 & 3.96 & 94.29 \\
Alkaloids $(\%)$ & 0.38 & 1.13 & 0.76 & 0.38 & 50.00 \\
Tannins $(\mathrm{mg} / 100 \mathrm{~g})$ & 14.03 & 5.46 & 9.75 & 4.29 & 44.00 \\
Cyanide $(\mathrm{mg} / 100 \mathrm{~g})$ & 14.85 & 4.17 & 9.51 & 5.34 & 56.15 \\
Phytate $(\mathrm{mg} / 100 \mathrm{~g})$ & 350.07 & 88.91 & 219.49 & 130.58 & 59.49 \\
\hline
\end{tabular}

$\mathrm{SD}=$ Standard deviation; RSD = Relative standard deviation.

Alkaloid concentrations were $0.38 \%$ in kernel and $1.13 \%$ in pulp samples. These values are very low compared to the reported $9.6 \%$ (lima bean) and $8.6 \%$ (scarlet runner bean) [87] and 5.0\% (black turtle bean) [82]. High level of alkaloids exerts toxicity and adverse effects to humans, especially in physiological and neurological activities. For instance, consumption of high tropane alkaloids will cause rapid heartbeat, paralysis and in fatal case, lead to death. However, lower dose of alkaloids mediate important pharmacological activities, such as analgesic, reducing blood pressure, killing tumour cells, stimulating circulation and respiration. Though dietary saponins exert various biological benefits, such as anti-inflammatory, anti diabetic, antiatherosclerotic and serve as protective functions like gastro-protective, hepatoprotective and hypolipidemic [88], they were found to affect protein digestibility by inhibiting various digestive enzymes such as trypsin and chymotrypsin [89], as well as reduce nutrient utilization and conversion efficiency [90]. The value of saponin for the kernel $(8.15 \%)$ is higher than the reported values of Vigna subterranea (4.6\%), Phaseolus coccineus (4.1\%) and Phaseolus lunatus (3.2\%) as reported by Aremu et al. [87].

The oxalate levels found in this work were 649.00 (kernel) and 221.50(pulp) mg/100 g of Vitellaria paradoxa. Oxalate serves as chelating agents and may chelate many toxic metals such as mercury and lead, but one major concern is its ability to trap heavy metals in the tissues of living organism thereby making elimination of them very difficult. In human body, oxalate in the form of oxalic acid combines with divalent metallic cations such as iron II $\left(\mathrm{Fe}^{+2}\right)$ and calcium $\left(\mathrm{Ca}^{2+}\right)$ to form crystals of the corresponding oxalates which are then excreted in urine as minute crystals. Oxalate crystals are razor sharp and may cause damage to various tissues. The sharp crystals cause damage due to their physical structure, but any contact with the crystals also increases inflammation. Iron oxalate crystals cause significant oxidative damage and diminish iron stores needed for red blood cell formation whereas many kidney stones result from calcium crystals. These oxalates can form larger kidney stones that can obstruct the kidney tubules. An estimated $80 \%$ of kidney stones are formed from calcium oxalate [91]. The kernel sample has oxalate value higher than the observed value of $254 \mathrm{mg} / 100 \mathrm{~g}$ in soybean and $286 \mathrm{mg} / 100 \mathrm{~g}$ for pigeon pea [92]; 495.0 $\mathrm{mg} / 100 \mathrm{~g}$ for scarlet runner bean, $490.6 \mathrm{mg} / 100 \mathrm{~g}$ for bambara groundnut [87], but the value is lower than 225740 and $166890 \mathrm{mg} / 100 \mathrm{~g}$ as found in red kidney bean and black turtle bean, respectively [82]. Phytate (a salt form of phytic acid) content were $350.07 \mathrm{mg} / 100 \mathrm{~g}$ in the seed and $88.91 \mathrm{mg} / 100 \mathrm{~g}$ in pulp sample (Table 6). The kernel sample value is comparable with $353.9 \mathrm{mg} / 100 \mathrm{~g}$ (bambara groundnut) and $365.5 \mathrm{mg} / 100 \mathrm{~g}$ (lima bean) [87], but it is lower than the values reported for soybean $(4050 \mathrm{mg} / 100 \mathrm{~g})$, pigeon pea $(1170 \mathrm{mg} / 100 \mathrm{~g})$ and cowpea $(2040 \mathrm{mg} / 100 \mathrm{~g})$ [92], black turtle bean (11250 mg/100 g) [82]. Phytic acid was reported to reduce blood glucose and possesses health benefits to diabetic patients. This is because the anti-nutrients concentration of phytic acid reduces the rate of starch digestion and slows down the gastric emptying which in turn, lowers blood glucose. However, excessive amounts of phytic acid in the diet will form insoluble complexes with multicharged metals [93], such as copper (II), zinc (II), 
calcium (II) and iron (III). This results in a deficit of the absorption of some dietary minerals and leads to mineral deficiencies. Cyanide is the chemical substance responsible for tissue hypoxia, and chronic exposure to it particularly hydrogen cyanide may cause neurological, respiratory, cardiovascular and thyroid defects [94]. The cyanide levels found in this work were 14.85 and $4.17 \mathrm{mg} / 100 \mathrm{~g}$ for kernel and pulp samples, respectively. The observed kernel value is higher than the early findings of Owolabi et al. [95] on cowpea seed (3.7 mg/100 g) and Zafar et al. [96] on Achnatherum hymenoides, but lower than $40.78 \mathrm{mg} / 100 \mathrm{~g}$ of Dioclea reflexa seed reported by Bolanle and Adedayo [97].

\section{Conclusion}

Compositional evaluation of kernel and pulp of shea-butter (Vitellaria paradoxa) fruit was presented in this study, which showed that kernel sample has high fat and energy contents with nutritionally valuable minerals comparable with known fat-rich plant based foods, such as groundnut and soybean. The result also revealed that essential amino acids were present in appreciable amount for both the kernel and pulp however supplementation of all the essential amino acids may be required in order to meet FAO/WHO diet requirement. Some antinutritive factors such as oxalate, saponin, alkaloids, tannins, cyanide and phytate were detected and were present in relatively high quantities particularly oxalate and phytate; these factors may pose a nutritional problem in its consumption. Reduction of these anti-nutrients during the processing of Vitellaria paradoxa kernel such as boiling is therefore of great importance for the safety of this fruit.

\section{Acknowledgements}

One of the authors, Professor Matthew Olaleke Aremu wishes to appreciate Ms. Maria Obegu of the office of Dean of Pure and Applied Sciences, Federal University Wukari for making the fruits of shea (Vitellaria paradoxa) available for the research. Dr. T. O. Ojobe, a former Chief Technologist of Zoology Department, University of Jos, Nigeria is also appreciated for amino acids analysis carried out in his laboratory.

\section{Conflict of Interest}

Authors declare that there are no conflicts of interest in the study.

\section{References}

1. Nahm, S.H., Juliani, R.H. and Simon, E.J. (2013). Quality characteristics of shea butter - Vitellaria paradoxa. In: African Natural Plant Products Volume II: Discoveries and Challenges in Chemistry, Health, and Nutrition; Juliani, H. et al.; ACS Symposium Series; American Chemical Society: Washington, DC, pp: $167-184$.
2. Moharram, H., Julie, R., Sibel, O., Hector, J. and James, S. (2006). Shea Butter: Chemistry, Quality, and New Market Potentials. In Herbs: Challenges in Chemistry and Biology; Wang, M. et al.; ACS Symposium Series; American Chemical Society: Washington, DC, pp: $324-340$.

3. Chalfin, B. (2004). Shea Butter Republic: State Power, Global Markets, and the Making of an Indigenous Commodity. New York, USA: Routledge, pp: $1-40$.

4. Obioma, U.N., Frank, U.E., Ikpendu, C.O. and Michael, U.A. (2000). Compositional and toxicological studies on shea butter. J. Nutraceuticals, Functional \& Med. Foods, 2(3): $33-39$.

5. Gilani, G.S., Cockell, K.A. and Sepehr, E. (2005). Effects of antinutritional factors on protein digestibility and amino acid availability in foods. JAOAC Int., 88: $967-987$.

6. Sarwar, G. and Brule, D. (1991). Assessment of the uricogenic potential of processed foods based on the nature and quantity of dietary purines. Prog. Food Nutr. Sci., 15: $159-181$.

7. Audu, S. S. and Aremu, M.O. (2011). Nutritional composition of raw and processed pinto bean (Phaseolus vulgaris L.) grown in Nigeria. J. Food Agric Environ, 9(3\&4): $72-80$.

8. Keay R.W.J. (1986). Trees of Nigeria. Clarendon Press, Oxford, p. 476.

9. Warra, A.A. (2011). Cosmetic Potentials of African Shea Nut (Vitellaria paradoxa) Butter. Current Res. in Chem., 1 -7 .

10. Umobong E.A. (2006). How to profit from the massive shea butter export boom! Success Digest., pp. 8-11.

11. AOAC (2007). Official Methods of Analysis. 18th Edition, Association of Official Analytical chemists, Gaithersburg.

12. Pearson, D. (1976). Chemical Analysis of Foods. 7th edn. J and A Churchill, London, UK, pp. 7-11.

13. FAO/WHO (1991). Protein Quality Evaluation Report of Joint FAO/WHO Expert Consultative FAO, Food and Nutrient.

14. Freidman, M. and Finely, J.W. (1971). Methods of tryptophan analysis. J. Agric. Food Chem., 19: 626-631.

15. Olaofe, O. and Akintayo, E.T. (2000). Prediction of isoelectric points of legume and oil seed proteins from amino acid composition. J. Technoscience, 4: 49-53.

16. Alsmeyer, R.H., Cunningham, A.E. and Happich, M.L. (1974). Equation to predict (PER) from amino acid analysis. Food Technology, 28: $34-38$.

17. Bradbury, M.G., Egen, S.V. and Bradbury, J.H. (1999) Determination of all forms of cyanogens in cassava roots and cassava products using picrate paperkits. J. Sci. Food Agric., 79: $593-601$

18. Olonisakin, A., Aremu, M.O. and Omonigbehin, E.A (2004). Phytochemical and antimicrobial investigations of extractive from Phyllantus amarus. Biosci. Biotech. Res.,Asia,

19. 2(1): $33-36$

20. Paul, A. and Southgate, D. (1978). The Composition of Foods. 4th Edn. Eleservier, North

21. Kilgore, O.F.G. Mastering Nutrients. Macmillan Education Ltd. London, UK, 1987, pp. 95 - 96.

22. Apiamu, A., Evuen, F.U., Igunbor, C.O. and Ozemoya, O.M. (2015). In vitro assessment of proximate and phytochemical quantifications of some edible fruits. Nig. J. Pharmac. and Appl. Sci. Res., 4(1): $1-9$.

23. Ogunlade, I., Ilugbiyin, A. and Osasona, I.A. (2011) Comparative study of proximate composition, anti-nutrient composition and functional properties of Pachira glabra and Afzelia africana seed flours. Afr. J. Food Sci., 5(1): $32-35$.

24. Amoo, I.A. and Agunbiade, F.O. (2009). Some nutrient and anti-nutrient components of Pterygota macrocarpa. The Pacific J. Sci. and Techn., 10(2): 949 - 955.

25. Ajayi, O.B., Akomolafe, S.F. and Adefioye, A. (2014) Proximate analysis, mineral contents, amino acid 
composition, anti-nutrients and phytochemical screening of Brachystegia eurycoma Harms and Pipper guineense Schum and Thonn. Am. J. Food and Nutr., 2(1): $11-17$

26. Akoja, S.S. and Amoo, I.A. (2011). Proximate composition of some under-exploited leguminous crop seeds. Pak. J. Nutr., 10(2): 143 - 146

27. Ibrahim, H., Aremu, M.O., Onwuka, J.C., Atolaiye, B.O. and Muhammad, J. (2016). Amino acid composition of pulp and seed of baobab (Adansonia digitata L.). FUW Trends in Sci. \& Techn. J., 1(1): $74-79$.

28. Ogbuagu, M.N. and Agu, B. (2008). Fruit nutritive composition of Maesobotrya barteri, an under-exploited tropical African tree. Fruits, 63(6): 357 - 361

29. Ogbe, A.O. and John, P.A. (2012). Proximate study, mineral and anti-nutrient composition of Moringa oleifera leaves harvested from Lafia, Nigeria: Potential benefits in poultry nutrition and health. J. Microbio., Biotech. and Food Sci., 1(3): $296-308$.

30. Aremu, M.O., Oko, O.J., Ibrahim, H., Basu, S.K., Andrew, C. and Ortutu, S.C. (2015). Compositional evaluation of pulp and seed of blood plum (Haematostaphis barteri), a wild tree found in Taraba State, Nigeria. Advances in Life Sci. and Techn., 33: 9 - 17.

31. Aremu, M.O., Olaofe, O. and Akintayo, E.T. (2006). Mineral and amino acid compostion of two varieties of bambara groundnut (Vigna subterranean) and Kersting's groundnut (Kerstingiella geocarpa) flour. Int. J. Chem., 16 $57-64$.

32. Sampaio, M.R., Marcos, K.S., Moraes, C.F.I. and Perez, H.V. (2009). Moisture adsorption behavior of biscuits formulated using wheat, oatmeal and passion fruit flour. $\mathbf{J}$. Food Processing and Preserv., 33(1): $105-113$.

33. Ijeomah, A.U., Ugwuona, F.U. and Ibrahim, Y. (2012). Nutrient composition of three commonly consumed indigenous vegetables of north-central Nigeria. Nig. J. Agric., Food and Env., 8(1): $17-21$.

34. Tosh, S.M. and Yada, S. (2010). Dietary fibres in pulse seeds and fractions: Characterization, functional attributes, and applications. Food Research Int'1., 43: 450 - 460.

35. Saldanha, L.G. (1995). Fiber in the diet of U.S. children: Results of national surveys. Paediatrics, 96: 994 - 996.

36. UICC/WHO (2005). Global Action Against Cancer. UICC and WHO Publications Department, Geneva.

37. Akachukwu, C.O. and Fawusi, M.O.A. (1995). Growth characteristic, yield and nutritive values of waterleaf. Discovery and Innovations, 7(2): $163-172$

38. Suarez, F.L., Springfield, J., Furne, J.K., Lohrmann, T.T., Kerr, P.S. and Levitt, M.D. (1999). Gas production in humans ingesting soybean flour derived from beans naturally low in oligosaccharides. Am. J. Clinical Nutr., 69(1): $135-139$

39. Ibrahim, T. A. and Fagbohun, E. D. (2012). Phytochemical and nutritive quality of dried seeds of Bacchhotzia coriacea. Greener Journal of Physical Sciences, 2: $185-191$.

40. Adeleke, R.O. and Abiodun, O.A. (2010). Chemical composition of three traditional vegetables in Nigeria. Pak. J. Nutr., 9(9): $858-860$.

41. Okullo, J.B.L., Omujal, F., Agea, J.G., Vuzi, P.C. Namutebi, A., Okello, J.B.A. and Nyanzi, S.A. (2010). Proximate and mineral composition of shea (Vitellaria paradoxa C.F. Gaertn) fruit pulp in Uganda. Afr. J. Food, Agric., Nutr. and Dev., 10(11): 4430 - 4443.

42. Asaolu, S.S., Adefemi, O.S., Oyakilome, I.G., Ajibulu, K.E. and Asaolu, M.F. (2012). Proximate and mineral composition of Nigerian leafy vegetables. Journal of Food Research, 1(3): $214-218$

43. Arewande, J.O. and Borokini, F.B. (2010). Comparative study on chemical composition and functional properties of three Nigerian legumes (Jack beans, pigeon pea and cowpea). JETEAS, 1(1): 89 - 95 .
44. Oboh, H., Anthony, O. and Adeyinka, O. (2010). Glycemic response of some boiled legumes commonly eaten in Nigeria. Original Research Art., 1 - 7.

45. Agunbiade, S.O., Amosu, A.M., Degun, A.M. and Omeonu, P.E. (2011). The physio-chemical and organoleptic properties of milk fabricated from Glycine max, vigna susterranean and sphegnostylis stenocarpa, J. Chem. Pharm. Res., 3(6): 918 - 924.

46. Ene-Obong, H. N. (1992). Nutritional evaluation, composition pattern and processing of underutilized traditional foods particular reference to the African yambeans (Sphenostylis stenocarpa). Ph.D Thesis, Department of Home Science and Nutrition, University of Nigeria, Nsukka.

47. Effiong, G.S., Ibia, T.O. and Udofia, U.S. (2009). Nutritive and energy values of some wild fruit spices in South Eastern Nigeria. Electronic J. Env., Agric. and Food Chem., 8(10): $917-923$

48. Ali, A. (2010). A comparative study of nutrients and mineral molar ratios of some plant foods with recommended dietary allowances. J. Food Sci. and Techn., 2(2): 104 - 108.

49. Pamela, C.C., Richard, A.H. and Denise, R.F. (2005). Lippincotts illustrated Reviews Biochemistry 3rd ed., Lippincott Williams and Wilkins, Philadelphia, pp. $335-$ 388.

50. Elias, L. G., Cristales, F.R., Bressani, R. and Miranda, H. (1976). Chemical composition and nutritive value of some grain legumes nutrient. Abstract Revised (Series B/1977), 47: $603-864$.

51. Salunkhe, D.K., Kadam, S.S. and Chavan, J.K. (1985). CRC Postharvest Biotechnology of Food Legumes. Boca Raton, FL: CRC Press.

52. Maranz, S. and Wiesman, Z. (2004). Influence of climate on the tocopherol content of shea butter. J. Agric. Food Chem., 52: 2934-2937.

53. Onimawo, I.A. (2002). Proximate composition and selected physicochemical properties of the seed, pulp and oil of soursop (Annona muricata). Plant Foods for Human Nutr., 57(2): $165-171$

54. Oyeleke, G.O., Salam, M.A. and Adetoro, R.O. (2012). Some aspects of nutrient analysis of seed, pulp and oil of Baobab (Adansonia digitata L.). IOSR J. of Env. Sci., Toxicol. and Food Techn., 1(4): 32 - 35

55. FAO (1990). Traditional food plants, Food Agric. Organisation of United Nation Nutritional Paper, 42: 593.

56. Aremu, M.O., Olaofe, O. and Akintayo, E.T. (2006). Chemical composition and physicochemical characteristics of two varieties of bambara groundnut (Vigna subterrenea) flours. J. Applied Sciences, 6(9): 1900 - 1903

57. Fleck, H. (1976). Introduction to Nutrition. 3rd edn Macmillian Publishing Co. Inc. New York NY, pp. 207219.

58. Shills, M.E. (1973). Magnesium. In: Fleck, H. (ed.), Introduction to Nutrition, 3rd edn. Macmillian Publishing Co. Inc., New York NY, p. 215.

59. Shills, M.Y.G. and Young, U.R (1992). Modern nutrition in health and disease. In: Nieman, D.C., Butterworth, D.E. and Nieman, C.N. (eds.). Nutrition. WmC, Brown Publishers, Dubuque, I.A., pp. 276-282.

60. Adeyeye, E.I. and Aremu, M.O. (2016). Chemical composition of whole shrimp, flesh and shell of Pandalas borealis) from Lagos atlantic ocean. FUW Trends in Sci. and Techn. J., 1(1): 26-32.

61. Bonger, R.H., Bode-Boger, S.M., Mugge, A., Klenke, S., Brandes, R.,Dwenger, A. and Frollich, J.C. (1996) Supplementation of hypercholesterolemic rabbits with LArg reduces the vascular release of superoxide anions and restores NO production. Atherosclerosis, 117: 273 - 284

62. Robinson, D.E. (1987). Food Biochemistry and Nutritional Value. Longman Scientific and Technology, Burnmell, Haslow, England, pp. 327 - 328. 
63. Olaofe, O., Okiribiti, B.Y. and Aremu, M. O. (2008). Chemical evaluation of the nutritive value of smooth luffa (Luffa cylindrica) seed's kernel. Electronic J. Env. and Agric. Food Chem., 7(10): 3444 - 3452.

64. Olubunmi, A.O., Olaofe, O. and Akinyeye, R.O. (2015) Amino acid composition of ten commonly eaten indigenous leafy vegetables of south-west Nigeria. World J. Nutr. and Health, 3(1): $16-21$

65. FAO/WHO/UNU (1985). Energy and Protein Requirements; Report of a Joint FAO/WHO/UNU Expert Consultation, WHO Tech Rep Ser no. 724. Geneva: WHO

66. Bingham, S., 1977. Dictionary of Nutrition, Barrie and Jenkins Limited, London, pp. 76-281.

67. Gold, C.M. (2009). The nine essential amino acids. CMG Archives. http://campbelmgold.com.

68. Arowora, K.A., Ezeonu, C.S., Imo, C. and Nkaa, C.G. (2017). Protein levels and amino acids composition in some leaf vegetables sold at Wukari in Taraba State, Nigeria. Int J. Bio. Sci. and Applications, 4(2): 19 - 24.

69. Audu, S.S. and Aremu, M.O. (2011). Effects of processing on chemical composition of red kidney bean (Phaseolus vulgaries L.) flour. Pak. J. Nutri., 10(11): 1069 - 1075.

70. Oyetayo, F.L. and Ojo, B.A. (2012). Food value and phytochemical composition of Luffa cylindrica seed flour. Am. J. Biochem., 2(6): 98 - 103.

71. Aremu, M.O., Bamidele, T.O., Agere, H., Ibrahim, H. and Aremu, S.O. (2015). Proximate composition and amino acid profile of raw and cooked black variety of tiger nut (Cyperus esculentus L.) grown in northeast Nigeria. J. Bio., Agr. Healthcare, 5(7): 213 - 221

72. Kritchevsky, D., (1979). Vegetable protein and atherosclerosis. J. Am. Oil Chem. Soc., 56: 135 - 140.

73. Belvady, B. and Gopalem, C. (1969). The role of leucine in the pathogenesis of canine black tongue and pellagra. Lancet, 2: 956 - 957

74. Ghafoornissa, S. and Narasinga, B.S. (1973). Effect of leucine on enzymes of the tryptophan niacin metabolic pathway in rat liver and kidney. Biochemistry Journal, 134: $425-430$.

75. Pellet, P.L. and Young, V.R. (1998). Nutritional evaluation of protein foods, Report of a working group sponsored by the International Union of Nutritional Sciences and the United Nations University World Hunger Programme. The United Nations University.

76. Adeyeye, E.I., Akinyeye, R.O., Ogunlade, I., Olaofe, O. and Boluwade, J.O. (2010). Effect of farm and industrial processing on the amino acid profile of cocoa beans. Food Chemistry J., 118: 337 - 363.

77. Fathima, K.R., Soris, P.T. and Mohan, V.R. (2010) Nutritional and anti-nutritional assessment of Mucana puriens (L.) DC var. puriens an under-utilized tribal pulse. Advances in Bioresearch, 1(2): $79-89$

78. Sobowale, S.S., Olatidoye, O.P., Olorode, O.O. and Akinlotan, J.V. (2011). Nutritional potentials and chemical value of some tropical leafy vegetables consumed in South West Nigeria. J. Sci. and Multidiscip. Res., 3: 55 - 65

79. FAO/WHO (1970). Amino acid content of foods and biological data in protein. FAO Nutritional Studies, No. 34 , FAO, Rome.

80. Adeyeye, E.I. (2006). Amino acids composition of fermented African locust bean (Parkia biglobosa) seeds. J. Appl. and Env. Sci., 2(2): 154 - 158.

81. Adeyeye, E.I. and Afolabi, E.O. (2004). Amino acid composition of three different types of land snails consumed in Nigeria. Food Chemistry, 85(4): 535 - 539.

82. Mendoza, C. (2002). Effect of genetically modified low phytic acid plants on mineral absorption. Int. J. Food Sci. \& Techn., 37(7): 759 - 767.
83. Audu, S.S., Aremu, M.O. and Lajide, L. (2013). Effects of processing on physicochemical and antinutritional properties of black turtle bean (Phaseolus vulgaris L.) seeds flour. Oriental J. Chem., 29(3): 979 - 989.

84. Ogunkoya, M.O., Abulude, F.O. and Oni, A.B. (2006) Determination of anatomical, proximate, minerals, oxalate, tannin and phytate compositions in Cuban boa (Epicrates anquifer). Electronic J. Env. Agric. and Food Chem., 5(1): $1161-1166$

85. Soetan, K.O., Olaiya, C.O. and Oyewole, O.E. (2010). The importance of mineral elements for humans, domestic animals and plants: A review. Afr. J. Food Sci., 4(5): $200-$ 222.

86. Enijuigha, V.N. and Agbede, J.O. (2000). Nutritional and antinutrtional characteristics of African oil bean (Pentaclethra macrohylla Benth) seeds. Appl. Tropical Agric.., 5(1): 11 - 14.

87. Mehansho, A., Buttler, L.G. and Carbon, D. M. (1987) Dietary tannin and salivary proline-rich proteins: interaction and defense mechanism. Annual Rev. Nutr., 7: 423 - 430.

88. Aremu, M.O., Ibrahim, H. and Ekanem, B.E. (2016). Effect of processing on in-vitro protein digestibility and antinutritional properties of three underutilized legumes grown in Nigeria. British Biotech. J., 14(1): $1-10$.

89. Banno, N., Akihisa, T., Tokuda, H., Yasukawa, K., Higashihara, H., Ukiya, M., Watanabe, K., Kimura, Y., Hasegawa, J. and Nishino, H. (2004). Triterpene acids from the leaves of Perilla frutescenes and their anti-inflammatory and antitumour-promoting effects. Biosci. Biotechn. and Biochem., 68: 85 - 90.

90. Shimoyamada, M., Ikedo, S., Ootsubo, R. and Watanabe, K. (1998). Effects of soybean saponins on chymotryptic hydrolyses of soybean protein. J. Agric. and Food Chem., 46: 4793 - 4797.

91. Sen, S., Makkar, H.P. and Becker, K. (1998). Alfafa saponins and their implication in animal nutrition. J. Agric. and Food Chem., 46: $131-140$.

92. Coe, F.L., Evan, A. and Worcester, E. (2005). Kidney stone disease. J. Clin. Invest. 115(10): 2598 - 2608.

93. Carnovale, E., Lugaro, E. and Marconi, E. (1991). Protein quality and antinutritional factors in wild and cultivated species of Vigna spp. Plant Foods Hum Nutr., 41: $11-20$.

94. Nolan, K.B., Duffin, P.A. and McWeeney, D.J. (1987) Effect of phytate on mineral bioavailability. In-vitro studies on $\mathrm{Mg} 2+, \mathrm{Ca} 2+, \mathrm{Cu} 2+, \mathrm{Zn} 2+$ and $\mathrm{Fe} 3+($ also $\mathrm{Cd} 2+)$ solubilities in the presence of phytate. J. Sci. and Food Agric., 40: 79 - 85

95. Priya, K.D., Pachiappan, C., Sylvia, J. and Aruna, R.M. (2011). Study of the effects of hydrogen cyanide exposure in Cassava workers. Indian J. Occup. Environ. Med., 15(3): $133-136$.

96. Owolabi, A.O., Ndidi, U.S., James, B.D. and Amune, F.A (2012). Proximate, antinutrient and mineral composition of five varieties (improved and local) of cowpea, Vigna unguiculata, commonly consumed in Samaru community, Zaria-Nigeria. Asian J. Food Sci. Technol., 4: 70 - 72.

97. Zafar, I.K., Kafeel, A., Asma, Z., Humayun, B., Abrar, H., Zile, H., Hazoor, A.S., Muhammad, S., Ghulam, H., Ijaz, R.N., Nudrat, A.A., Muhammad, A., Fahim, A., Irfan, M., Vincenzo, T., Mariano, F. and Eugenio, C. (2015). Assessment of poisonous and anti-nutritional compounds in wild edible forages consumed by ruminant species. J. Env. Sci. and Techn., 8(3): $91-101$.

98. Bolanle, A.O. and Adedayo,A. (2012). Comparative study on chemical compositions, phytochemical screening and physico-chemical properties of the seeds of Dioclea reflexa. Ultra Chem., 8: $251-264$. 